\title{
Hour Times Picomole per Milliliter
}

National Cancer Institute

\section{Source}

National Cancer Institute. Hour Times Picomole per Milliliter. NCI Thesaurus. Code C85640.

Hours times picomoles per milliliter. 